\title{
Design With Nature at 50: retrospect and prospect
}

\author{
A special issue dedicated to the fine memories of lan L. McHarg (1920-2001) \\ who continues to be a sources of ecophronesis and inspiration
}

(c) Springer Nature Singapore Pte Ltd. 2019

Frederick R. Steiner and Billy Fleming, guest editors
Ian L. McHarg Center for Urbanism and Ecology
Stuart Weitzman School of Design
University of Pennsylvania, Philadelphia, USA

"And when there are 100 million more of us ... will our cities be sicker still, our suburbs just as sick, our landscape further befouled? That's likely to be so, Mate. And the reason is simple: We are a man-centered society. We have never learned that we're a part of nature.

Show me any civilization that believes that reality exists only because man can perceive it, that the cosmos was erected to support man on its pinnacle, that man-exclusively-is divine, and then I will predict the nature of its cities and landscape; the hot dog stands, the neon shill, the ticky-tacky houses, the sterile core, the mined and ravaged countryside. This is the image of anthropocentric man. He seeks not unity with nature but conquest. Yet, unity he finds when his arrogance and ignorance are still and he lies dead under the greensward."

Ian L. McHarg, from his introduction to Multiply and Subdue the Earth, a 1969 documentary film produced for public television in the USA 